\title{
Loan as a Durable Good and Bank Indirect-Tax Incidence
}

\author{
Gerasimos T. Soldatos ${ }^{1} \&$ Erotokritos Varelas ${ }^{2}$ \\ ${ }^{1}$ American University of Athens, Greece \\ ${ }^{2}$ University of Macedonia, Greece \\ Corresponsence: Gerasimos T. Soldatos, American University of Athens, Greece.
}

Received: July 30, 2015

Accepted: October 30, 2015

Online Published: November 30, 2015

doi:10.5430/ijfr.v7n1p33

URL: http://dx.doi.org/10.5430/ijfr.v7n1p33

\begin{abstract}
This paper maintains that the durable-goods character of loans enables the forward shift of bank indirect taxes $\grave{a}$ la Coase (1972), increasing thereby the money multiplier and reducing the equity-lending ratio regardless bank industry structure. Consequently, policymakers may use such taxes countercyclically if, of course, the need for depositor insurance is not exaggerated evoking upon the problems of asymmetric information accompanying lending. Also, the "standard" proposition that the ability to shift indirect taxation forward depends negatively on the size of the elasticity of loan demand, is confirmed here, too. The low elasticity of loan demand is related with relationship banking, contemplating thereby that the mix "bank indirect tax-relationship banking" may prove to be critical for capital accumulation and growth depending on the dissemination of such banking. A zero-bank-profit policy is proposed as a stabilization policy beyond the countercyclical manipulation of the tax.
\end{abstract}

Keywords: loan life, bank indirect-tax incidence, bank market power, quantity competition, capital accumulation

\section{Introduction}

Contrary to what authors like Albertazzi and Gambacorta (2010), Caminal (2003), Chiorazzo and Milani (2011), and Demirgüc-Kunt and Huizinga (1999, 2001) maintain, Cappele-Blancard and Havrylchyk (2013a, b) retort that a tax on bank profit cannot be shifted forward to customers, because it does not affect the optimization problem of the bank. And, they become the first to tackle the issue of the incidence of a bank tax as an indirect rather than corporate income tax. Through a Cournot version of the Monti-Klein model and empirical analysis of the Hungarian bank tax, they confirm the conventional wisdom that in an oligopolistic market, the ability to shift forward indirect taxation depends negatively on the size of the elasticity of demand (see e.g. Fullerton and Metcalf 2002, and Konrad et al. 2014). But, when the question of indirect tax incidence comes to bank asset taxes, it should not be ignored that what banks sell is a durable good, since loans is what they sell, and loans need time to be paid off, with the installments being really rents and some part of the loan remaining unpaid before maturity date. And, when one goes over the also scarce literature on indirect taxation and market power in the oligopolistic environment of the durable goods industry (see e.g. Goering and Boyce 1996), the following Coase-type (1972) argument might be advanced with regard to banks:

Borrowers anticipate that the bank will have an incentive to reduce future interest rates due to either a rightward shift of the supply curve of loans under prosperity conditions or a leftward shift of the demand curve for loans under recessionary conditions. This reduces the value of current loans, which loans however are already held by borrowers, and which value reduction need not be taken thereby into account by the bank when formulating its future pricing strategy unless it is explicitly stated in the loan contract. Rational individuals, who wish to borrow now, will take this into consideration, inducing subsequently the bank to act accordingly through marginal cost pricing unless the life span of the loan is small enough to be disassociated from future pricing decisions. That is, the bank can exercise its market power and earn positive profit only if borrower rationality is somehow disturbed. And, a bank tax can be such a disturbance factor within the context of course of oligopolistic banking: The bank can simply ascribe the levy of a higher interest on the presence of the tax, in which case part of the profit may be seen as coming out of a tax shift. At the same time, the bank can lend the tax money saved through the shift, driving the interest rate down, which borrowers can "guess" too, ameliorating bank market power to shift the tax. The extent of the shift depends on the interplay of these two trends. (Note 1) 
The various plans for additional bank taxation following the Lehman brothers' crisis in 2009, is a development conferring to a study in bank indirect tax incidence even more importance. These have been plans which according to the European Commission's Eurobarometer (No. 75, 2011) are looked upon favorably by 81 percent of Europeans. Their implementation would undoubtedly offset the possible economic rents conferred to the financial sector by the explicit and inexplicit state support to it (see e.g. Chaudhry and Mullineux 2014). But, there does exist ability to shift the taxes, and this is a subject that should be researched in more detail given that what is known for sure is only that the tax shift will hurt more seriously small firms and households. The redistributive effect of any taxation is expected and is defined to be the content of tax incidence, indeed (Pearce, 1986, p. 192). Nevertheless, if the tax shift, any tax shift, influences capital accumulation, a "second-order", "long-term" redistributive effect exists too, and is part of the overall tax incidence. This is at least the viewpoint from which this paper approaches the subject matter under investigation.

The next section examines these considerations formally through a stylized two-period Cournot Monti-Klein model. The results of this investigation not only corroborate the main thesis of this paper about bank indirect-tax induced bank market power to shift the tax forward, but they want it to hold regardless bank industry structure. The magnitude of the shift and its effect on capital accumulation depends on the extent to which the tax-shift investment disincentive is counterbalanced in the market by the effect of the shift-induced money-multiplier increase on the interest rate. Moreover, the "standard" proposition that the ability to shift indirect taxation forward depends negatively on the size of the elasticity of loan demand, is confirmed here, too. Section 3 is motivated by policy considerations, introducing into the discussion lending out of own bank funds. Relating the low elasticity of loan demand with relationship banking, and by contemplating thereby that the mix "bank indirect tax - relationship banking" may prove to be a factor influencing capital accumulation, a zero-bank-profit policy or the same, full-reserve requirement is proposed. Indirect taxation is found to lower the equity-lending ratio as well, and in this connection, its countercyclical manipulation is proposed, too. Section 4 concludes this paper with a discussion on the appropriate policy-making towards the banking sector. Countries which do not have such a tax, should take these considerations into account in the design of the tax system.

\section{Analysis}

Let there be $N$ identical banks, each providing $L$ loans, based on $D$ deposits, through the bank-money multiplier $1 / e, 0<e<1$, so that $D=e L$, where $e$ is the required reserves ratio. The life span of a loan is two periods, with $h L, 0<h<1$, of it, remaining to be paid off when period 2 begins; $h$ is determined institutionally. The inverse demand function for loans in period $1, r_{1}\left(L_{1}\right)$, represents the interest rate, $r_{1}$, borrowers are willing to pay for $L_{1}$ so that $r_{1}=r_{1}\left(L_{1}\right)$, while the interest rate corresponding to period $2, r_{2}$, reflects borrower willingness to pay not only for $L_{2}$ but for $h L_{1}$ too, so that $r_{2}=r_{2}\left(h L_{1}+L_{2}\right)$. Hence, in the presence of a tax rate $t$ on loans, if $i$ is the deposit rate, $b$ is the one-period discount factor, and $C=\delta D+\lambda L$ is the cost function for the typical bank, with $\delta$ and $\lambda$ being positive parameters, the $n$th bank, $n=1,2, \ldots, N$, is called for in a Cournot setting to maximize profit:

$$
\Pi=\left\{\left[r_{1}\left(L_{1}\right)-\lambda_{1}\right] L_{1}-\left(i_{1}-\delta_{1}\right) D_{1}-t_{1} L_{1}\right\}+b\left\{\left[r_{2}\left(h L_{1}+L_{2}\right)-\lambda_{2}\right]\left(h L_{1}+L_{2}\right)-\left(i_{2}-\delta_{2}\right) D_{2}-t_{2} L_{2}\right\}
$$
or since $D=e L$ :

$$
\Pi=\left\{\left[r_{1}\left(L_{1}\right)-\lambda_{1}\right]-e_{1}\left(i_{1}-\delta_{1}\right)-t_{1}\right\} L_{1}+b\left\{\left[r_{2}\left(h L_{1}+L_{2}\right)-\lambda_{2}\right]\left(h L_{1}+L_{2}\right)-e_{2}\left(i_{2}-\delta_{2}\right) L_{2}-t_{2} L_{2}\right\}
$$

taking for granted the strategies of the other $N-1$ banks, where the subscript " $n$ " has been suppressed due to the assumption of identical banks.

Now, note that the first-order condition for the maximization of the second-period profit, $\Pi_{2}=\left[r_{2}\left(h L_{1}+L_{2}\right)-\right.$ $\left.\lambda_{2}\right]\left(h L_{1}+L_{2}\right)-e_{2}\left(i_{2}-\delta_{2}\right) L_{2}-t_{2} L_{2}$, is:

$$
\frac{\partial \Pi_{2}}{\partial L_{2}}=\left[r_{2}\left(h L_{1}+L_{2}\right)-\lambda_{2}\right]+L_{2} \frac{\partial r_{2}\left(h L_{1}+L_{2}\right)}{\partial L_{2}}-e_{2}\left(i_{2}-\delta_{2}\right)-t_{2}=0
$$

which when solved for $L_{2}$, implies that the solution, $L_{2}^{*}$, depends on the first-period choice of $L_{1}$. If this is common knowledge so that first-period borrowers know about it, banks cannot maximize (1) without taking into that borrowers expect (2) and hence, banks are constrained by (2). The impact of this constraint on bank's response to taxation is given by the derivative:

$$
\frac{\partial \Pi}{\partial t_{2}}=\left(\frac{\partial L_{2}^{*}}{\partial t_{2}} h L_{1}^{*} \frac{\partial r_{2}}{\partial L_{2}}-b L_{2}\right)
$$


A priori, both derivatives inside the parentheses should be negative, rendering the whole term to the left of $-L_{2}$ positive and counteracting thereby the negative quantity $-L_{2}$. Let us, for instance, postulate for simplicity a reciprocal interest rate function, $r(\cdot) \equiv(\cdot)^{-1}$ so that $L_{2}^{*}=\left(\sqrt{h L_{1} \Gamma}-\Gamma\right) / \Gamma$, with $h L_{1}>\Gamma$, and

$$
\frac{\partial L_{2}^{*}}{\partial t_{2}}=-\frac{\sqrt{h L_{1}}}{2 \Gamma \sqrt{\Gamma}}<0
$$

Where, $\Gamma \equiv t_{2}+e_{2}\left(i_{2}-\delta_{2}\right)+\lambda_{2}$.

Consequently,

$$
\frac{\partial \Pi}{\partial t_{2}}=b\left\{\left[-\frac{\sqrt{h L_{1}}}{2 \Gamma \sqrt{\Gamma}}\right] h L_{1}^{*}\left[-\frac{1}{\left(h L_{1}+L_{2}\right)^{2}}\right]-b L_{2}\right\}
$$

Where, $-\left(h L_{1}+L_{2}\right)^{-2}=\partial r_{2} / \partial L_{2}$.

To understand the meaning of (4) and by extension of (3), note that $\partial \Pi / \partial t_{1}=-L_{1}$, that is, the tax in period 1 is a pure loss for the bank. The same would be true for period 2 if the positive term to the left of $-b L_{2}$ in (4) and (3) was not there; it is a term which owes to the borrower expectations constraint (2) and which might neutralize and even benefit the bank to the extent that it is equal or greater than $L_{2}$. What is for sure is that the tax in period 2 increases the market power of banks, which might be interpreted as bank ability to shift the tax partly or wholly and profit even further just because not all of $L_{1}$ is owned by the bank in period 2. In period 1, before part $(1-h)$ of the loan has been paid out, the bank is burdened by the loan wholly and can do nothing directly to shift the tax. It can do it indirectly, however, by letting it affect borrower expectations for period 2: It can simply state in the beginning of the loan that no better terms can be offered for the loan because of the tax. In the case of positive (3) or (4), not only the whole of $t_{2}$ will have been shifted but part of $t_{1}$, too. One benchmark case is the complete shift of the tax without any further profit, i.e. the case of $\Pi=0$ in (1) so that:

$$
t_{1} L_{1}+b t_{2} L_{2}=\left[\left(r_{1}-\lambda_{1}\right)+b h\left(r_{2}-\lambda_{2}\right)-e_{1}\left(i_{1}-\delta_{1}\right)\right] L_{1}+b\left[r_{2}-\lambda_{2}-e_{2}\left(i_{2}-\delta_{2}\right)\right] L_{2} .
$$

This is marginal-cost pricing inclusive of the tax. The left-hand side of (5) gives the total tax imposed on the bank, but shifted to the borrower. The other benchmark case is the zero shift: the tax is imposed when $t_{1} L_{1}+b t_{2} L_{2}=0$ in (5) and $\Pi$ is reduced exactly by that amount after the levy of the tax. This is the case of marginal-cost pricing exclusive of the tax, the case according to which taxation in period 2 does not confer market power: the bank cannot or does not have an incentive to evoke upon the presence of taxation to frustrate borrower interest-rate expectations for period 2. A zero-bank-profit policy would achieve just that as discussed in the concluding section, but not before the following capital-accumulation considerations are also taken into account:

If the longevity of a loan is seen from an intergenerational perspective, the shift of the indirect bank tax may be attributed to the role of banking as a non-market surrogate of insurance against intergenerational liquidity shocks (Diamond and Dybvig 1983). The banks exploit this role to shift the tax to the current generation, to the businesses mostly signing loan contracts now, thus lowering capital accumulation. At the other end, banks have an incentive to lend more. The borrower does understand that in view of the tax, the bank should at least break even as under pre-tax marginal cost pricing. And, since $t \Pi<\Pi=0$ in any one period, the borrower does understand that there has to be an increase in the lending rate for the bank to break even after the tax. But, $\mathrm{s} / \mathrm{he}$ also senses that taxation strengthens the bank's incentive to lend, because $D=e L=>D>t e L$. The money multiplier is raised from $1 / e$ to $1 / t e$, given that both $t$ and $e$ are less than 1. The additional amount of loans comes out of this increase: from the tax money saved through the tax shift, driving the interest rate down. The extent to which the rightward shift of the loan supply curve counteracts with the upward pressure that the increased bank market power exerts on the interest rate and the subsequent course of capital accumulation, is a matter of empirical considerations. In the case, for example, of the reciprocal interest-rate function, what is for sure from the comparison of $L_{2}^{*}=\left(\sqrt{h L_{1} \Gamma}-\Gamma\right) / \Gamma$ with and without the tax $t_{2}$, is that the after-tax optimal $L_{2}, L_{2}^{*}$, exceeds the pre-tax one, with the comparison being reduced to the inequality:

$$
2 \Gamma \hat{\Gamma} \sqrt{h L_{1} \hat{\Gamma}}+2 t_{2} \Gamma \sqrt{h L_{1} \hat{\Gamma}}+t_{2} \hat{\Gamma}\left(1-t_{2}\right)>t_{2} h L_{1} \Gamma+2 \Gamma \sqrt{h L_{1} \Gamma},
$$

where $\hat{\Gamma} \equiv \Gamma-t_{2}=\left[e_{2}\left(i_{2}-\delta_{2}\right)+\lambda_{2}\right]$. The extent of the difference between the two sides of this inequality depends on the particular specification of the parameters and variables involved in it.

If the introduction of the indirect tax alters the pre-tax course of capital accumulation, and if this course is the one at steady-state, the tax will be at odds with the efficient Arrow-Debreu intergenerational insurer role, which banks are supposed to play. But, if the effects of the tax acts as a stabilizing factor as, for instance, by lowering the interest rate 
under recessionary conditions, the tax will be working towards improving efficiency, falsifying those who see in the banking sector only a destabilizing influence. Much more so when these results obtain regardless bank industry structure, since the term $1 /(N+1)$, which should accompany individual Cournot bank lending in either period, is found in either side of (5) and just cancels out: Under quantity competition, taxation confers market power regardless the structure of the banking industry; power in the sense of profit-making out of which taxes may be paid and working thereby as a forward shift of the tax. Quantity and in general non-price competition is a plausible assumption for the banking sector, given the concern of the state with the interest rates.

\section{Policy Considerations}

The point is that increased market power signifies increased price mark-up; and part of the increased price has been taken above to be covering partly or wholly the indirect bank tax, having per se this tax-shift an adverse effect on capital accumulation. And, two are the points that need to be made in connection with policy-making to the extent that the tax-shift induced increase of the money-multiplier cannot reverse this adversity: First, note that by multiplying and dividing (3) with $L_{2} / r_{2}$, (3) becomes:

$$
\frac{\partial \Pi}{\partial t_{2}}=\left(\frac{\partial L_{2}^{*}}{\partial t_{2}} h \frac{L_{1}^{*}}{L_{2}^{*}} \frac{r_{2}}{\sigma_{2}}-b L_{2}\right),
$$

where $\sigma_{2}$ is the elasticity of the demand for $L_{2}$, thus confirming the "standard" proposition that the ability to shift indirect taxation forward depends negatively on the size of the elasticity of loan demand. Consequently, the tax burden is likely to be borne by low demand elasticity borrowers. Such are surely the elasticity conditions forged by relationship banking. Privileged banking protects from adverse business conditions (Berlin and Mester 1999), and the "protected" firm might be viewing the bank tax shift as an additional intertemporal insurance premium. And, note that nowadays, good business is identified with such banking. Now, if this mutual firm-bank understanding is actually the case, and if there is a discrepancy between the firm-bank private interest and the societal good of higher capital accumulation and growth: Should the government regulate against relationship banking?

This is the question prompting the second point that needs to be made with regard to policy-making. The answer to it is a matter of (dis)incentives, for which critical within the context of our model is the role of the reserve requirement ratio, $e$. Note that from (5), the smaller $e$ is, the less revenue the bank needs to break even before the tax ceteris paribus, the easier thereby to collect this revenue, the easier a tax shift would become and hence, once full tax shift is possible, the larger the tax that might be shifted. Therefore, the answer to the above question would be in the affirmative only if the government was postulating a full-reserve requirement, since in this manner, neither the bank nor the firm would have an incentive to commit to privileged banking. But, note that as mentioned in the last section in a discussion of (5) too, a zero-bank-profit policy would have the same outcome, indeed, because what is sought by either policy is the zeroing of commercial bank seigniorage (see e.g. Soldatos and Varelas 2014). This "mandate" is in the spirit of the pre-WWII, non-monetarist, Chicago School of Thought, because "[t]he fixing of the quantity of circulating media is attractive as a principle of monetary policy for several reasons..." (Simons 1936, p. 5).

And, there does exist room for policy intervention given the evidence for bank indirect-tax shift mentioned in the introductory section. The shift induced loan supply expansion does not appear to be outweighing the interest rate increase brought about by increased bank market power to shift the tax. How could when the interest rate is too low to be contemplating further reduction in connection with the tax shift? One reason for the current trend of the interest rate is the weak connection of the reserve requirement ratio with modern banking business and hence, of the money multiplier in determining lending expansion and the market interest rate. Under these circumstances, a zero-bank-profit policy intervention becomes meritless, let alone the fact that such an intervention is seen nowadays as outdated. But, these are circumstances placing the emphasis on financial discipline and bank supervision rather than on the macroeconomic role of banking. This is the reason for the limited nowadays role of $e$ and for the current unpopularity of a zero-bank-profit rule. This change of emphasis on policy might had been in the right direction given that neither tax-shifts would have been documented under a near liquidity-trap interest rate, since $\sigma_{2}$ (and $\sigma_{1}$ ?) above would have been effectively zero. Yet, the tax shift exists and is unrelated with the trends in the interest rate, because policy preoccupation with depositor insurance (esp. Basel Agreement) has led to lending influenced greatly by bank own capital, with the equity-lending ratio being regulated inappropriately in so far as the macroeconomía is concerned. Besanko and Kanatas (1996) argue among others that high capital requirements reduce monitoring incentives and decrease the quality of banks' assets while Blum (1999) adds that they also increase the value of future profits for banks and induce banks to more risk taking. The fact is that banks lend today based on a multiple of their equity rather than on any reserve requirement ratio; a regulated multiple mismatching macroeconomic trends, which explains why increased lending cannot take away bank market power. 
That regulatory intervention is to blame for the trends contradicting our theoretical predictions, may be easily seen by introducing into the analysis some deposit insurance premium, $P$, and own bank funds, $E$, so that $L+P=D+$ $E$. If $q$ is the probability of loan repayment, $P=D+E-L$ has to be equal to $(1-q) D$ so that $D+E-L=$ $(1-q) D=>$

$$
L=q D+E
$$

for the bank to break even, ceteris paribus. Moreover, shareholders' value

$$
P\{[r(L)-\lambda] L-(i-\delta) D\} \geq q\{[r(L)-\lambda] L-(i-\delta) D\}
$$

or

$$
L \geq \frac{(i-\delta)(1-q)}{(P-q)[r(L)-\lambda]} D
$$

to ensure the continuation of bank's operations. Solving (8) for D, inserting the result (with the equality sign) in (6), and dividing by $L$, yields that:

$$
k=1-\frac{q(P-q)[r(L)-\lambda]}{(i-\delta)(1-q)}
$$

while multiplying $L$ in (7) by $t$, and proceeding with the same operations, one obtains that:

$$
k=1-\frac{t q(P-q)[r(L)-\lambda]}{(i-\delta)(1-q)}
$$

which is clearly less than the $k$ in (9) given that $t<1$. The introduction of indirect taxation lowers rather than raises the multiple $k$ of loans based on bank own funds, as it should be the case given the increase in the money multiplier. So, if the opposite actually happened in reality, it should be attributed purely to the regulation of $k$. (Note 2) A regulation disregarding the message of these considerations that better than financial discipline and bank supervision appears to be that fiscal policy which is based on raising/lowering indirect taxation as an instrument of boosting/restraining the economy during recession/inflation. Much more so when as Blum and Hellwig (1995) caution, capital requirements manipulation appears to amplify cyclical fluctuations. Handling bank indirect taxation in a countercyclical manner would too be in the spirit of non-monetarist Chicago School, complementing the zero-bank-profit rule, if it was undertaken within the broader context of a cyclically balanced budget.

\section{Discussion}

To sum up, the durable-goods character of loans enables the forward shift of bank indirect taxes à la Coase (1972), increasing thereby the money multiplier and reducing the equity-lending ratio. Consequently, policymakers may use such taxes countercyclically if, of course, the need for depositor insurance is not exaggerated evoking upon the microeconomic problems of adverse selection and moral hazard before and after lending, respectively. These problems may be severe, indeed. Guillaume (2013) argues, for example, that moral hazard may be accompanied by ex post adverse selection, with the ex ante incentives for effort to be interacting with ex post incentives to misreport to the lending bank, impeding subsequently the design of any optimal contract. Deposits will be in jeopardy if cases like this become widespread, and financial discipline and/or bank supervision should be sought policy-wise. Nevertheless, what really puts depositors at risk is that if it is costly to enforce loan contracts, borrowing capacity will become limited, and the need to relax credit constraints on the part of the borrowing firm, may give rise to the so-called "financial accelerator" of amplifying macroeconomic fluctuations (see e.g. Liu and Wang 2014). So, a policy towards the banking sector should be as much microeconomics minded as macroeconomic-stability oriented. This is the principle according to which bank indirect taxation should be treated given the sizeable effect of this taxation on the monetary economy. A principle admittedly having always in mind that "regulatory policy motivated only by macroeconomic goals may destroy banks by preventing them from providing the services that are the raison d'être of banks... [and may] go so far as to suggest implicitly that we have no need for banks at all since banks can be replaced by other existing institutions (e.g., mutual funds)" (Diamond and Dybvig 1986, p. 56).

\section{References}

Albertazzi, U., \& Gambacorta, L. (2010). Bank Profitability and Taxation. Journal of Banking and Finance, 34(11), 2801-2810. http://dx.doi.org/10.1016/j.jbankfin.2010.06.003

Berlin, M., \& Mester, L. J. (1999). Deposits and Relationship Lending. Review of Financial Studies, 12(3), 579-607. 
Besanko, D., \& Kanatas, G. (1996). The Regulation of Bank Capital: Do Capital Standards Promote Bank Safety? Journal of Financial Intermediation, 5, 160-83. http://dx.doi.org/10.1006/jfin.1996.0009

Blum, J. (1999). Do Capital Adequacy Requirements Reduce Risk in Banking? Journal of Banking and Finance, 23(5), 755-771. http://dx.doi.org/10.1016/S0378-4266(98)00113-7

Blum, J., \& Hellwig, M. (1995). The Macroeconomic Implications of Capital Adequacy Requirements for Banks. European Economic Review, 39(3-4), 739-749. http://dx.doi.org/10.1016/0014-2921(94)00081-A

Caminal, R. (2003). Taxation of Banks; Modeling the Impact. In P. Phonohan (Ed.), Taxation of financial intermediation: Theory and practice for emerging economies (pp. 31-80). The World Bank and Oxford University Press.

Capelle-Blancard, G., \& Havrylchyk, O. (2013a). The Ability of Banks to Shift Corporate Income Taxes to Customers, CEPII Working Paper No 2013-09, Paris. Retrieved from http://www.cepii.fr/PDF_PUB/wp/2013/wp2013-09.pdf

Capelle-Blancard, G., \& Havrylchyk, O. (2013b). Incidence of Bank Levy and Bank Market Power, CEPII Working Paper No 2013-21, Paris. Retrieved from http://www.cepii.fr/PDF_PUB/wp/2013/wp2013-21.pdf

Chaudhry, S. M., \& Mullineux, A. W. (Eds) (2014). Taxing Banks Fairly. Cheltenham, UK: Elgar. http://dx.doi.org/10.4337/9781783476480

Chiorazzo, V., \& Milani, C. (2011). The Impact of Taxation on Bank Profits: Evidence from EU Banks. Journal of Banking and Finance, 35, 3202-3212. http://dx.doi.org/10.1016/j.jbankfin.2011.05.002

Coase, R. H. (1972). Durability and Monopoly. Journal of Law and Economics, 15(1), 143-149.

Demirgüc-Kunt, A., \& Huizinga, H. (1999). Determinants of Commercial Bank Interest Margins and Profitability: Some International Evidence. World Bank Economic Review, 13(2), 379-408.

Demirgüc-Kunt, A., \& Huizinga, H. (2001). The Taxation of Domestic and Foreign Banking. Journal of Public Economics, 79, 429-453. http://dx.doi.org/10.1016/S0047-2727(00)00071-2

Diamond, D. W., \& Dybvig, P. H. (1983). Bank Runs, Deposit Insurance, and Liquidity. Journal of Political Economy, 91, 401-419. http://dx.doi.org/10.1086/261155

Diamond, D. W., \& Dybvig, P. H. (1986). Banking Theory, Deposit Insurance, and Bank Regulation. Journal of Business, 59(1), 55-68. http://dx.doi.org/10.1086/296314

Fullerton, D., \& Metcalf, G. E. (2002). Tax Incidence. In A.J. Auerbach, \& M. Feldstein (Eds.), Handbook of Public Economics (Vol. 4). Amsterdam: Elsevier. http://dx.doi.org/10.3386/w8829

Goering, G. E., \& Boyce, J. R. (1996). Taxation and Market Power when Products are Durable. Journal of Regulatory Economics, 9, 83-94. http://dx.doi.org/10.1007/BF00134820

Guillaume, R. (2013). Optimal Contract under Moral Hazard with Soft Information. American Economic Journal: Microeconomics, 5(4), 55-80. http://dx.doi.org/10.1257/mic.5.4.55

Konrad, K. A., Morath, F., \& Muller, W. (2014). Taxation and Market Power. Canadian Journal of Economics/Revue Canadienne d'Economique, 47(1), 173-202. http://dx.doi.org/10.1111/caje.12067

Liu, Z., \& Wang, P. (2014). Credit Constraints and Self-Fulfilling Business Cycles. American Economic Journal: Macroeconomics, 6(1), 32-69. http://dx.doi.org/10.1257/mac.6.1.32

Pearce, D. W. (1986). The MIT Dictionary of Modern Economics. Cambridge, MA: MIT Press.

Simons, H. (1936). Rules versus Authorities in Monetary Policy. Journal of Political Economy, 44(1), 1-30.

Soldatos, G. T., \& Varelas, E. (2014). A Letter on Full-Reserve Banking and Friedman's Rule in Chicago Tradition. Kredit und Kapital / Credit and Capital Markets, 4(47), 677-687. http://dx.doi.org/10.3790/ccm.47.4.677

\section{Notes}

Note 1. If, at the other end, interest rate increases rather than decreases are expected, the shortest possible loan duration will be pursued by the borrower ceteris paribus, inducing thereby the bank to internalize the tax.

Note 2. It is noteworthy that introducing a tax $\tau$ on shareholders' value in (8), $\tau$ would cancel out and would not subsequently alter $k$, confirming from still another perspective the traditional thesis that income taxation does not affect incentives. 